\title{
THE LINK BETWEEN CARBON EMISSIONS, AGRICULTURAL OUTPUT AND INDUSTRIAL OUTPUT: EVIDENCE FROM SOUTH AFRICA
}

\author{
Mabutho SIBANDA@*, Hlengiwe NDLELA \\ College of Law and Management Studies, University of KwaZulu-Natal, \\ Durban, South Africa
}

Received 22 February 2019; accepted 11 September 2019

\begin{abstract}
This study seeks to establish the relationship between carbon emissions, agricultural output and industrial output in South Africa. It uses data from 1960 to 2017 based on an annual frequency, giving a total of 58 annual observations. The Autoregressive Distributed Lag technique is employed to estimate the model on a bivariate basis. The evidence shows that carbon emissions are not influenced by agricultural and industrial output. Conversely, agricultural output is influenced by carbon emissions and industrial output. The results suggest that climate change resulting from carbon emissions has led to reduced agricultural output, adversely affecting food security. The significant relationship between industrial and agricultural output suggests that a properly functioning industrial sector will cause an increase in the agricultural output. The study's findings have implications for climate change and manufacturing policies in South Africa.
\end{abstract}

Keywords: agricultural output, carbon emissions, climate change, $\mathrm{CO}_{2}$, greenhouse gases, industrialization, industrial output.

JEL Classification: G20, G21, L11, L60, Q11, Q14, Q53, Q54.

\section{Introduction}

Carbon dioxide emissions $\left(\mathrm{CO}_{2}\right)$ and climate change are topical issues in all spheres of society, with nations striving to reduce the adverse effects of industrialization on climate. Over the last couple of decades, on one hand, the global economy has witnessed massive industrialization and urbanization (Gollin, Jedwab, \& Vollrath, 2016); on the other hand, there have been calls for efficient food production to meet the increasing demand for food globally amid recurrent droughts and adverse weather patterns (Clark \& Tilman, 2017; Bai, Deng, Jiang, Zhao, \& Miao, 2018). Both agriculture and industrialization have competing demands to mitigate carbon emissions. Estimating a co-integrating relationship between agricultural out-

*Corresponding author. E-mail: sibandam@ukzn.ac.za 
put and carbon emissions and between industrial output and carbon emissions is important in ascertaining how these two sectors contribute to climate change. The study addresses two questions about the direction of causality between agricultural output and carbon emissions, and between industrial output and carbon emissions. As an addition, the study establishes whether there is a relationship between agricultural output and industrial output as these two sectors are interdependent for raw materials and inputs. In that regard, the study will provide evidence of co-integration or absence thereof between the two sectors.

Climate change has become a global priority with countries committing to the United Nations Kyoto Protocol, which came into effect in 2005. The protocol states that greenhouse gas emissions should be reduced to save the planet. In addition, the Paris Agreement that was adopted in 2015 committed countries to a global goal to reduce carbon emissions based on what each considered fair and ambitious. According to Feig, Joubert, Mudau, and Monteiro (2017), 40 per cent of anthropogenic emissions has been trapped in the atmosphere since 1750 , while the rest has been removed by ocean and vegetation sinks. South Africa is the $13^{\text {th }}$ largest carbon emitter in the world and the largest in Africa with an estimated 8.9 tonnes per capita. Energy is the main contributor to carbon emissions in South Africa. It contributes directly and indirectly to such emissions as factors like industrial and agricultural production produce greenhouse gases.

The agricultural sector in South Africa has experienced diverse structural changes since the advent of democracy in 1994. Although the country has a dual agricultural economy commercial farming and small-scale farming - the sector has shifted from low-value, highvolume farming for domestic consumption to high-value products for the export market. Thus, an increase in farm production and agricultural intensity, with a focus on the increased use of irrigation, fuel, fertilizer, mechanization and genetically modified techniques, could have a negative impact on the environment. This creates new input costs which are currently not included in the pricing of agricultural commodities. According to Goldbatt (2018), these costs could be borne by the next generation's individual taxpayers. Agriculture contributes about 4 per cent to Gross Domestic Product (GDP) and mainly consists of cattle and sheep as crop farming only takes place on 13 per cent of agricultural land. However, value addition from agro-processing makes a significant contribution to the amount generated by the manufacturing sector (Statistics South Africa, 2019). Manufacturing itself contributes approximately 13 per cent of GDP. It is largely dominated by industries like automotive, chemicals, information and communication technology, electronics, metals, textiles and clothing and footwear.

This study is based on the foundations of sustainable development (green growth). Green growth encompasses inclusive development that takes into account the boundaries of environmental factors (Van Vuuren et al., 2017). In addition, the Environmental Kuznets Curve (EKC) informs this study. The EKC hypothesizes that as the country embarks on economic development, environmental degradation is expected to worsen, up to a certain level before improving. This study seeks to establish the relationship between carbon emissions, agricultural output and industrial output in South Africa. The following section provides a review of existing literature on the linkages between these three variables. The paper is structured as follows: The next section provides a review of existing theoretical and empirical literature on 
the relationship between carbon emissions and agricultural output and carbon emissions and industrial output. The research methodology is discussed thereafter, followed by the results and discussion. Finally, the conclusion is provided at the end together with the implications of the study, limitations of the study and directions for further research.

\section{Literature review}

Since the seminal work of Simon Kuznets in 1955, there has been a debate on how economic growth (and its indicators) behave in relation to economic inequality. Kuznets (1955) hypothesized that a shift from agriculture (due to mechanization) has important implications on industrialization and urbanization in the process of economic growth. Thus in theory, as the economy develops and goes through industrialization, there is a tendency for this nation to shift towards cities leading to increases in economic inequalities up to a certain point then a decrease. In light of this, economists have identified the Environmental Kuznets Curve (EKC) hypothesis as an explanatory technique to anchor environmental policy (Agras \& Chapman, 1999; Dinda, 2004; Sarkodie \& Strezov, 2018). EKC postulates that environmental quality tends to decrease as the economy grows until a certain point before it improves (Apergis \& Ozturk, 2015). This relationship takes the form of an 'inverted U' shape. Thus, economic growth, through whatever form, is the ultimate solution to environmental degradation. Given the hypothesized relationship between economic growth and environmental quality, this study considers industrialization and agriculture as pivotal economic sectors for economic growth. As industrialization and agricultural output increase, it is conceptualized that as per EKC, carbon emissions will increase up to a certain point before decreasing.

Research on the link between agriculture and carbon emissions is gaining momentum, as more research is essential to reduce carbon emissions globally (Gold, 2016). Acknowledging the impact of carbon emissions and climate change, Altieri and Nicholls (2017) argue that traditional farming methods, mainly used by peasant farmers, are important to increase agricultural yields. For instance, increasing agricultural input efficiency reduces agriculture's adverse effects on the environment (Clark \& Tilman, 2017). Jebli and Youssef's (2017) study in North America found short- and long-run bidirectional causality between agriculture and emissions and concluded that in the long run, increases in agricultural production reduces $\mathrm{CO}_{2}$ emissions. However, as the population grows, demand for food increases, leading to higher carbon emissions hence the need for efficient agricultural productivity (Van Vuuren et al., 2017; Ma et al., 2019). Population growth leads to urbanization, which has been found to Granger cause carbon emissions. Alam, Murad, Noman and Ozturk (2016) found relationships between income and energy use and carbon emissions, confirming the findings of Van Vuuren et al. (2017). Agricultural production efficiency plays an important role in reducing carbon emissions. For example, Bennetzen, Smith, and Porter (2016) established that highly industrialized and intensive systems produce the lowest carbon emissions per unit of agricultural production.

Although energy production and consumption have been identified as key drivers of greenhouse gas emissions, carbon emissions from agriculture remain important as nations 
strive to ensure food security (Li, Baležentis, Makutėnienè, Streimikiene, \& Kriščiukaitienè, 2016). According to Moore and Diaz (2015), climate change resulting from carbon emissions has resulted in reduced agricultural output, adversely affecting food security. A study in Ghana showed evidence of a causal relationship between carbon dioxide emissions and agriculture which could be the result of growing food demand in the country (AsumaduSarkodie \& Owusu, 2016). However, the effects of carbon emissions on agriculture decreased periodically over time. Agricultural output also leads to carbon emissions in intermediate use and final demand for the product by the domestic sector. However, Lin and Xie (2016) and Davis et al. (2016) argue that efficiencies in agricultural production will not reduce carbon emissions due to the increasing global demand for food.

The agricultural sector does not only produce carbon dioxide emissions but methane and nitrous oxide as well (Cole et al., 1995, 1997). According to Cole et al. (1997), these three are the main contributors of greenhouse gas emissions in the agricultural sector and emanate mainly from population growth, increased demand for food and change in land use. According to Follett (1993) and Zhang, Pang, Chen, and Lu (2019), agriculture plays a vital role in the mitigation of climate change and hence efficient agricultural production should reduce the quantity of carbon emissions. Agriculture helps in reducing carbon emissions as arable land sinks some of the emissions and sequestrate it into organic matter and for use as biomass (Sauerbeck, 2001). To mitigate carbon emissions, according to Smith et al. (2007), efficient and improved use of agricultural land could potentially mitigate greenhouse gas emissions. In this regard, Friel et al. (2009) argue that food production, mainly from the livestock sector, is responsible for four-fifths of agricultural emissions worldwide. However, according to Pant (2009), agriculture could have both positive and negative effects on climate; firstly, positive effects in that higher concentration of carbon dioxide in the atmosphere increases plant photosynthesis and thus crop yields; and finally, increases in temperature resulting from carbon emissions adversely affect crop yields. Thus, there is a possible bidirectional causality between carbon emissions and agricultural output.

Industry is the major source of carbon emissions among all economic sectors, primarily due to high-energy usage by the sector (Liu, Fan, Wu, \& Wei, 2007; Xu, He, \& Long, 2014; Du, Zhou, Pan, Sun, \& Wu, 2019). Earlier, Keeling (1973) had also argued that industrial and domestic activities were responsible for the increased amount of carbon emissions. Wang, Zhang, Liu, and Bi (2012) concur and provide evidence that industrial energy consumption and industrial processes contribute the highest carbon emissions in cities, mainly due to urbanization and need for industrial output for economic growth. Economic growth from industrial activities is a major contributor of carbon emissions globally (Liu, Wang, Wu, \& Wei, 2010). Consequently, the reduction of industrial carbon emissions remains a vital mitigation strategy for developing countries (Chen \& Timilsina, 2012). However, in an earlier study, Liaskas, Mavrotas, Mandaraka, and Diakoulaki (2000) argue that it is possible to reduce carbon emissions from manufacturing without adversely impacting on economic growth by adopting optimal energy mix. In addition, Chen, Gao, and He (2004) simulated the impact of carbon restrictions in China and found that the carbon emission strategies could adversely affect economic growth if implemented. There is, therefore, no consensus on how industrial carbon emissions could affect industrial output and vice versa. 
Victor (2017) postulates that the quantity of waste products from production processes should be sufficient to meet the physical law of the conservation mass. However, according to Kanemoto, Moran, and Hertwich (2016), increased consumption of energy-intensive products by wealthy countries results in carbon leakage, shifting emissions across countries. Wang and Yang (2015) argue that economic activity is a major contributor to high carbon emissions while the industry structure plays a vital role in their reduction. They assert that rather than growing and expanding secondary industries, countries should focus on tertiary industries to lower carbon emissions. Consistent with Wang and Yang's arguments, a study in Turkey established that manufacturing contributes to carbon emissions, although at different levels depending on the supply chain (Kucukvar, Cansev, Egilmez, Onat, \& Samadi, 2016).

It is expected that as manufacturing output increases, a country will experience economic growth, which subsequently increases carbon emissions (Begum, Sohag, Abdullah, \& Jaafar, 2015; Li \& Lin, 2015; Xu \& Lin, 2015). Different stages of production contribute to carbon emissions differently with the industrial sector contributing the largest level (Xu, He, Long, \& Chen, 2016; Mi, Pan, Yu, and Wei, 2015). Although changing the industry structure could lead to reduced carbon emissions, it has an adverse effect on GDP (Chang, 2015). However, the industrial sector can also play an important role in reducing carbon emissions by using biomass for low-temperature heating services (Fais, Sabio, \& Strachan, 2016). Lin and Lei (2015) and Long, Luo, Wu, and Zhang (2018) add that while industrial production is a major contributor to carbon emissions, the current focus should be on improving energy efficiency. Evidence also shows that carbon emissions are more sensitive in industrial output than agricultural output as measured by value added to GDP (Burke, Shahiduzzaman, \& Stern, 2015).

Awokuse and Xie (2015) conducted an empirical study revisiting the link between agriculture and economic development and concluded that agriculture remains an important sector in boosting economic growth. Consequently, agriculture plays an important role in boosting the manufacturing sector in terms of trade and by increasing the capacity to import industrial inputs (de Souza, 2015). In that same vein, Uddin (2015) found bidirectional causality between agriculture and industrial output confirming the interdependency between these two sectors. The next section provides a discussion of the methodology used to establish the link between carbon emissions, agricultural output and industrial output.

\section{Research methodology}

The study uses time series data obtained in the public domain. The three variables are carbon emissions $\left(\mathrm{CO}_{2}\right)$, agricultural output (Agric) and industrial output (Ind). Carbon emissions data was obtained from the World Bank database, while agricultural and industrial output are from the South African Reserve Bank (SARB) database. The study period is 1960 to 2017 based on an annual frequency, giving a total of 58 annual observations. Descriptive statistics and stationarity tests are conducted before the long-run estimations. The Autoregressive Distributed Lag (ARDL) co-integration technique recommended by M. H. Pesaran and B. Pesaran (1997), Pesaran and Shin (1998) and Pesaran, Shin, and Smith (2001) is used to test for a long-run relationship between carbon emissions, agricultural output and industrial output. The following basic model was estimated: 


$$
\Delta Y_{t}=\beta_{0}+\sum_{i=1}^{n} \beta_{i} \Delta y_{t-1}+\sum_{i=0}^{n} \delta_{i} \Delta x_{t-i}+\varphi_{1} y_{t-1}+\varphi_{2} x_{t-1}+\mu_{t},
$$

where: $\beta_{i}$ and $\delta_{i}$ are the short run coefficients, $\varphi_{1}$ and $\varphi_{2}$ are the ARDL long-run coefficients and $\mu_{\mathrm{t}}$ is the white noise term. The model specifications based on the estimation model above is as follows:

$$
\begin{aligned}
& \Delta \ln \left(\mathrm{CO}_{2}\right)_{t}=\beta_{0}+\sum_{i=1}^{n} \beta_{i} \Delta \ln \left(\mathrm{CO}_{2}\right)_{t-1}+\sum_{i=0}^{n} \delta_{i} \Delta \ln (\text { Ind })_{t-i}+ \\
& \varphi_{1} \ln \left(\mathrm{CO}_{2}\right)_{t-1}+\varphi_{2} \ln (\text { Ind })_{t-1}+\mu_{t} ; \\
& \Delta \ln \left(\mathrm{CO}_{2}\right)_{t}=\beta_{0}+\sum_{i=1}^{n} \beta_{i} \Delta \ln \left(\mathrm{CO}_{2}\right)_{t-1}+\sum_{i=0}^{n} \delta_{i} \Delta \ln (\text { Agric })_{t-i}+ \\
& \varphi_{1} \ln \left(\mathrm{CO}_{2}\right)_{t-1}+\varphi_{2} \ln (\text { Agric })_{t-1}+\mu_{t} ; \\
& \Delta \ln (\text { Ind })_{t}=\beta_{0}+\sum_{i=1}^{n} \beta_{i} \Delta \ln (\text { Ind })_{t-1}+\sum_{i=0}^{n} \delta_{i} \Delta \ln (\text { Agric })_{t-i}+ \\
& \varphi_{1} \ln (\text { Ind })_{t-1}+\varphi_{2} \ln (\text { Agric })_{t-1}+\mu_{t}
\end{aligned}
$$

where: $\beta_{i}$ are the short-run coefficients with $\Delta$ as the first-difference operator. Similar models are also estimated with the same variable but with current explanatory variables as the dependent variables. The $\varphi_{i}$ are the long-run coefficients used to test for a long-run cointegrating relationship between $\ln \mathrm{CO}_{2}$ and $\ln$ Agric and $\ln I n d$ and also between $\ln I n d$ and $\ln$ Agric. The estimation test hypothesis is that:

$$
\mathrm{H}_{0}: \varphi_{1}=\varphi_{2}=0 \text { against } \mathrm{H}_{1}: \varphi_{1}=\varphi_{2} \neq 0 .
$$

Rejection of the null hypothesis in favour of the alternative means that there is a long-run relationship between the variables. This would warrant the estimation of an error correction model, which captures the short-run dynamics of the long-run relationship by determining aspects such as the speed of adjustment back to equilibrium. The model is represented by Equations (5)-(7).

$$
\begin{aligned}
& \Delta \ln \left(\mathrm{CO}_{2}\right)_{t}=\vartheta_{0}+\vartheta_{1} \Delta \ln \left(\mathrm{CO}_{2}\right)_{t-i}+\vartheta_{2} \Delta \ln \left(\text { Agric }_{t-i}+\pi E C T_{t-1}+\epsilon_{t}\right. \\
& \Delta \ln \left(\mathrm{CO}_{2}\right)_{t}=\vartheta_{0}+\vartheta_{1} \Delta \ln \left(\mathrm{CO}_{2}\right)_{t-i}+\vartheta_{2} \Delta \ln (\text { Ind })_{t-i}+\pi E C T_{t-1}+\epsilon_{t} \\
& \Delta \ln (\text { Ind })_{t}=\vartheta_{0}+\vartheta_{1} \Delta \ln (\text { Ind })_{t-i}+\vartheta_{2} \Delta \ln (\text { Agric })_{t-i}+\pi E C T_{t-1}+\epsilon_{t} .
\end{aligned}
$$

In the case that there is no significant long-run relationship between the variables, a short-run model, as specified in Equation (6) is estimated instead of the error correction model.

$$
\begin{gathered}
\Delta \ln \left(\mathrm{CO}_{2}\right)_{t}=\theta_{0}+\theta_{1} \Delta \ln \left(\mathrm{CO}_{2}\right)_{t-i}+\theta_{2} \Delta \ln (\text { Agric })_{t-i}+\varepsilon_{t} \\
\Delta \ln \left(\mathrm{CO}_{2}\right)_{t}=\theta_{0}+\theta_{1} \Delta \ln \left(\mathrm{CO}_{2}\right)_{t-i}+\theta_{2} \Delta \ln (\text { Ind })_{t-i}+\varepsilon_{t}
\end{gathered}
$$




$$
\Delta \ln (\text { Ind })_{t}=\theta_{0}+\theta_{1} \Delta \ln (\text { Ind })_{t-i}+\theta_{2} \Delta \ln (\text { Agric })_{t-i}+\varepsilon_{t}
$$

where: The lagged first differenced values on the explanatory variables show the short-run causality between $\ln \mathrm{CO}_{2}$ and $\ln$ Agric. ECT is the error correction term; a negative and statistically significant coefficient on the ECT will mean long-run causality and correction back to equilibrium.

\section{Results}

\subsection{Descriptive statistics}

Table 1 presents the results of the descriptive statistics for the three variables - carbon emissions, and agricultural and industrial output. The average carbon emissions per annum were $305166.87 \mathrm{kt}$ when agricultural and industrial outputs were R182 223448275.86 and R516 888293103.45 , respectively. When the minimum agricultural and industrial output were R94 538000000 and R4 158000 000, the minimum carbon emissions were $97934.57 \mathrm{kt}$ and when the maximum agricultural and industrial output were R303 927000000 and R2 206 485000 000, the maximum carbon emissions were $503112.40 \mathrm{kt}$. This means that carbon emissions increase with agricultural and industrial production. Table 1 also shows that the variables are fairly symmetrical given the skewness values of between -0.5 and 0.5 , except for industrial output.

Table 1. Descriptive statistics

\begin{tabular}{|l|c|c|c|}
\hline & $\mathrm{CO}_{2}$ & Agric & Ind \\
\hline Mean & 305166.87 & 182223448275.86 & 516888293103.45 \\
\hline Median & 325312.40 & 180528500000 & 201971500000 \\
\hline Std. Dev & 129701.35 & 58820127703.52 & 637068466235.94 \\
\hline Kurtosis & -1.28 & -0.86 & 0.24 \\
\hline Skewness & -0.08 & 0.30 & 1.19 \\
\hline Minimum & 97934.57 & 94538000000 & 4158000000 \\
\hline Maximum & 503112.40 & 303927000000 & 2206485000000 \\
\hline Sum & 17699678.68 & 10568960000000 & 29979521000000 \\
\hline Count & 58 & 58 & 58 \\
\hline
\end{tabular}

\subsection{Stationarity and unit root tests}

Before the ARDL estimations, stationarity and unit root tests were conducted and the results are shown in Table 2. All the variables employed $-\ln \mathrm{CO}_{2}$, $\ln$ Agric and $\ln$ Ind - were either $\mathrm{I}(0)$ or I(1) based on the ADF and KPSS tests. This means that the ARDL model can be employed as none of the variables are I(2) or integrated of a higher order (Arshed, 2014). Therefore, the ARDL model was used to test the long-run relationships among these variables in their natural log form. 
Table 2. Stationarity and unit root tests

\begin{tabular}{|c|c|c|c|c|c|}
\hline \multirow{2}{*}{$\mathrm{ADF}$} & \multicolumn{2}{|c|}{$\mathrm{I}(0)$} & \multicolumn{2}{|c|}{$\mathrm{I}(1)$} & \multirow{2}{*}{$\begin{array}{l}\text { Order of } \\
\text { integration }\end{array}$} \\
\hline & $\mathrm{C}$ & $\mathrm{C}+$ @trend & $\mathrm{C}$ & C + @trend & \\
\hline LNAGRIC & 0.8723 & $-5.8417^{\star * *}$ & $-8.8046^{\star * *}$ & $-8.7237^{\star * *}$ & $\mathrm{I}(0)$ \\
\hline $\mathrm{LNCO}_{2}$ & -2.5107 & -1.2716 & $-6.9159^{\star * *}$ & $-7.4522^{* * *}$ & $\mathrm{I}(1)$ \\
\hline LNIND & -1.8927 & 0.1459 & $-4.0136^{\star * *}$ & $-4.5046^{* * *}$ & $\mathrm{I}(1)$ \\
\hline \multirow[t]{2}{*}{ KPSS } & \multicolumn{2}{|c|}{$\mathrm{I}(0)$} & \multicolumn{2}{|c|}{$\mathrm{I}(1)$} & \\
\hline & C & C + @trend & $\mathrm{C}$ & $\mathrm{C}+$ @trend & \\
\hline LNAGRIC & $0.9181^{* * *}$ & 0.1185 & 0.1426 & $0.1337^{\star}$ & $\mathrm{I}(1)$ \\
\hline $\mathrm{LNCO}_{2}$ & $0.8927^{\star * *}$ & $0.2455^{\star * *}$ & $0.4415^{*}$ & 0.0418 & $\mathrm{I}(1)$ \\
\hline LNIND & $0.9237^{\star * *}$ & $0.2088^{\star *}$ & $0.5615^{\star \star}$ & $0.2085^{\star *}$ & $\mathrm{I}(1)$ \\
\hline
\end{tabular}

\subsection{ARDL model estimation}

In estimating the ARDL models, the optimum lag length and best ARDL models were determined using the information criteria - the SBIC, AIC and HQIC. The maximum number of lags were tested up to four and in each of the estimations, $\operatorname{ARDL}(1,0)$ was chosen. This means that the information criteria designated a single lag on the dependent variable and no lag on the explanatory variable. Subsequent to the confirmation of the selected models, diagnostic tests were conducted on these models. The results from the tests showed that there was no serial autocorrelation and heteroscedasticity in any of the models. Model stability tests CUSUM and CUSUM of squares tests - also showed that the models were stable. Therefore, the bounds tests for co-integration were subsequently conducted.

Table 3. ARDL estimation - carbon emissions

\begin{tabular}{|c|c|c|c|}
\hline \multicolumn{2}{|c|}{ Dependent Variable: $\mathrm{D}\left(\mathrm{LNCO}_{2}\right)$} & \multicolumn{2}{|c|}{ Dependent Variable: $\mathrm{D}\left(\mathrm{LNCO}_{2}\right)$} \\
\hline Variable & Coefficient & Variable & Coefficient \\
\hline $\mathrm{C}$ & -0.439797 & C & 1.036124 \\
\hline $\mathrm{D}\left(\mathrm{LNCO}_{2}(-1)\right)$ & 0.033726 & $\mathrm{D}\left(\mathrm{LNCO}_{2}(-1)\right)$ & 0.040245 \\
\hline D(LNAGRIC(-1)) & -0.034202 & $\mathrm{D}(\operatorname{LNIND}(-1))$ & 0.186930 \\
\hline $\mathrm{LNCO}_{2}(-1)$ & -0.059988 & $\mathrm{LNCO}_{2}(-1)$ & -0.142642 \\
\hline LNAGRIC & 0.047080 & LNIND & 0.029403 \\
\hline \multicolumn{2}{|c|}{ Wald Test } & \multicolumn{2}{|c|}{ Wald Test } \\
\hline Test Statistic & Value & Test Statistic & Value \\
\hline F-statistic & 3.215624 & F-statistic & 3.734678 \\
\hline Chi-square & 6.431247 & Chi-square & 7.469355 \\
\hline
\end{tabular}


Table 4. ARDL estimation - agricultural production

\begin{tabular}{|l|c|l|c|}
\hline \multicolumn{2}{|c|}{ Dependent Variable: D(Lnagric) } & \multicolumn{2}{c|}{ Dependent Variable: D(Lnagric) } \\
\hline \multicolumn{1}{|c|}{ Variable } & Coefficient & \multicolumn{1}{c|}{ Variable } & Coefficient \\
\hline C & 9.899721 & C & 14.99968 \\
\hline D(LNAGRIC(-1)) & -0.046404 & D(LNAGRIC(-1)) & 0.011324 \\
\hline D(LNCO $\left._{2}(-1)\right)$ & -0.544045 & D(LNIND(-1)) & 0.178278 \\
\hline LNAGRIC(-1) $^{|c|}$ & -0.544193 & LNAGRIC(-1) & -0.686818 \\
\hline LNCO $_{2}$ Wald Test: & 0.335984 & LNIND & 0.107671 \\
\hline \multicolumn{2}{|c|}{ Test Statistic } & Value & \multicolumn{2}{c|}{ Test Statistic } & Vald Test: \\
\hline F-statistic & 8.175238 & F-statistic & 8.352887 \\
\hline Chi-square & 16.35048 & Chi-square & 16.70577 \\
\hline
\end{tabular}

Table 5. ARDL estimation - industrial production

\begin{tabular}{|l|c|l|c|}
\hline \multicolumn{2}{|c|}{ Dependent Variable: D(LNIND) } & \multicolumn{2}{c|}{ Dependent Variable: D(LNIND) } \\
\hline \multicolumn{1}{|c|}{ Variable } & Coefficient & \multicolumn{1}{c|}{ Variable } & Coefficient \\
\hline C & -1.005780 & C & -0.827791 \\
\hline D(LNIND(-1)) & 0.451719 & D $(\text { LNIND }(-1))_{2}$ & 0.370181 \\
\hline D(LNAGRIC(-1)) & 0.007712 & D LNCO $\left._{2}(-1)\right)$ & -0.133647 \\
\hline LNIND(-1) & -0.015544 & LNIND(-1) & -0.047536 \\
\hline LNAGRIC & 0.056554 & LNCO $_{2}$ & 0.168839 \\
\hline \multicolumn{2}{|c|}{ Wald Test: } & & \multicolumn{2}{c|}{ Test Statistic } & Vald Test: \\
\hline Test Statistic & Value & F-statistic & 4.373542 \\
\hline F-statistic & 2.039850 & Chi-square & 8.747084 \\
\hline Chi-square & 4.079700 & \multicolumn{2}{c}{} \\
\hline
\end{tabular}

In Table 3, based on the lower bound (4.94) and upper bound (5.73) critical values provided by Pesaran et al. (2001), the null hypothesis that there is no co-integration could not be rejected at $5 \%$ level of significance for $\mathrm{InCO}_{2}$ vs $\ln$ Agric, $\mathrm{InCO}_{2}$ vs $\ln I n d$, $\ln I n d$ vs $\ln A g$ ric and $\ln I n d$ vs $\operatorname{lnCO}_{2}$. All the estimated F-values 3.215624 ( $\mathrm{InCO}_{2}$ vs $\ln$ Agric), 3.734678 ( $\mathrm{InCO}_{2}$ vs $\operatorname{lnInd}$ ), 2.039850 (InInd vs $\ln$ Agric) and 4.373542 (InInd vs $\operatorname{lnCO} \mathrm{CO}_{2}$ ) - are less than the lower bound critical value (4.94). This suggests that there is no long-run relationship between these variables and only short run models, and not error correction models, can be estimated. On the other hand, Table 4 shows that the null hypothesis of no cointegration can be rejected at the $5 \%$ significance level for lnAgric vs $\operatorname{lnCO}_{2}($ F-statistic $=8.175238)$ and for lnAgric vs lnInd (F-statistic $=8.352887$ ). Both F-statistics are greater than the upper bound critical value of 5.73. For these two equations, error correction models could be estimated in order to get a better view of the short run dynamics. However, as shown in Table 5, both the F-statistic values of 2.039850 and 4.373542 are less than the upper bound critical value of 5.73 which suggests that error correction model cannot be estimated. 
The absence of a significant long run relationship between carbon emissions and agricultural and industrial output is quite surprising. It could mean that South Africa's production industrial and agriculture production does not produce a lot of carbon emissions to warrant a long run relationship among these sectors. However, such results are inconsistent with Li et al.s (2016) finding that carbon emissions from agriculture remain important as nations strive to meet food security. According to Moore and Diaz (2015), climate change resulting from carbon emissions has resulted in reduced agricultural output, adversely affecting food security. The need to meet growing food demand under the constraints of climate change results in further increases in carbon emissions (Asumadu-Sarkodie \& Owusu, 2016). The results from the study by Moore and Diaz (2015) could explain the negative coefficient on the $\ln \mathrm{CO}_{2}$ coefficient in the lnAgric equation as well as the significant relationship between the two climate change from carbon emissions may be affecting agricultural output in South Africa.

With regard to industrial output, the results are inconsistent with various international findings; increased manufacturing output that accompanies economic growth also increases carbon emissions (Begum et al., 2015; Li et al., 2016). The different production and processing stages in manufacturing produce high levels of carbon emissions. However, in South Africa, the largest industry is the mining industry and this does not produce the same quantity of carbon emissions as the manufacturing industry in most international studies. The significant relationship between agricultural output and industrial output and not vice versa suggests that only the agricultural sector is more dependent on the industrial sector and not vice versa. This is in contradiction with the finding that there is a form of interdependence between these sectors with the possible link being that they depend on each other for raw materials and inputs. This finding is also inconsistent with Murphy, Shleifer and Vishny's (1989) argument that agricultural productivity is a source of autonomous demand for manufactured goods and that income from agriculture leads to increased demand for mass-produced domestic goods.

\subsection{Short run estimations}

As in the case of the ARDL estimations above, diagnostic tests were conducted before any inferences were made on the error correction estimation results. All six models passed these tests. In the short run estimation, short run models were estimated for the variables which exhibited no long run significant cointegration and error correction models were estimated for the pairs of variables that exhibited a significant long run relationship. From Table 6, the only significant coefficient on an explanatory variable is that on $\operatorname{lnInd}$ in the $\operatorname{lnCO}_{2}$ equation. This is an indication of a short relationship between industrial production and carbon emissions, albeit significant at 10\% level. From Table 7, the error term coefficient was found to be negative and statistically significant in all three cases; $-0.549451^{\star * \star}$ for InAgric vs $\operatorname{lnCO}{ }_{2},-0.485392^{* *}$ for InAgric vs $\ln I n d$. These results show that about $55 \%$ and $49 \%$ of any disequilibrium between InAgric and $\operatorname{lnCO}_{2}$ and $\ln$ Agric and $\operatorname{lnInd}$, respectively, is corrected in each year. It means that full correction to equilibrium would take 1.82 years $(1 / 0.549451)$ and 2.06 years $(1 / 0.485392)$, respectively, between these variables. 
Table 6. Short run models

\begin{tabular}{|c|c|c|c|c|c|}
\hline \multicolumn{3}{|c|}{ Dependent Variable: $\mathrm{D}\left(\mathrm{LNCO}_{2}\right)$} & \multicolumn{3}{|c|}{ Dependent Variable: $\mathrm{D}\left(\mathrm{LNCO}_{2}\right)$} \\
\hline Variable & Coefficient & Prob. & Variable & Coefficient & Prob. \\
\hline $\mathrm{D}\left(\mathrm{LNCO}_{2}(-1)\right)$ & 0.070341 & 0.6139 & $\mathrm{D}\left(\mathrm{LNCO}_{2}(-1)\right)$ & 0.024924 & 0.8541 \\
\hline D(LNAGRIC(-1)) & -0.026616 & 0.6416 & $\mathrm{D}(\operatorname{LNIND}(-1))$ & 0.183974 & 0.0849 \\
\hline $\mathrm{C}$ & 0.026744 & 0.0007 & $\mathrm{C}$ & 0.007141 & 0.5917 \\
\hline \multicolumn{3}{|c|}{ Dependent Variable: D(LNIND) } & \multicolumn{3}{|c|}{ Dependent Variable: D(LNIND) } \\
\hline Variable & Coefficient & Prob. & Variable & Coefficient & Prob. \\
\hline $\mathrm{D}(\operatorname{LNIND}(-1))$ & 0.532967 & 0.0000 & $\mathrm{D}(\operatorname{LNIND}(-1))$ & 0.530883 & 0.0000 \\
\hline D(LNAGRIC(-1)) & 0.023229 & 0.7086 & $\mathrm{D}\left(\mathrm{LNCO}_{2}(-1)\right)$ & 0.024039 & 0.8754 \\
\hline C & 0.050919 & 0.0011 & $\mathrm{C}$ & 0.050869 & 0.0013 \\
\hline
\end{tabular}

Table 7. Error correction models

\begin{tabular}{|l|c|c|l|c|c|}
\hline \multicolumn{2}{|c|}{ Dependent Variable: D(LNAGRIC) } & \multicolumn{2}{c|}{ Dependent Variable: D(LNAGRIC) } \\
\hline \multicolumn{1}{|c|}{ Variable } & Coefficient & Prob. & Variable & Coefficient & Prob. \\
\hline C & 0.033334 & 0.0363 & C & 0.016921 & 0.5574 \\
\hline D(LNAGRIC(-1)) & -0.052854 & 0.7013 & D(LNAGRIC $(-1))$ & -0.114589 & 0.4035 \\
\hline D $\left(\right.$ LNCO $\left._{2}(-1)\right)$ & -0.504115 & 0.0968 & D (LNIND(-1)) & 0.028878 & 0.8997 \\
\hline ECT $(-1)$ & -0.549451 & 0.0003 & ECT $(-1)$ & -0.485392 & 0.0012 \\
\hline
\end{tabular}

Table 8. Short run causality test

\begin{tabular}{|c|c|c|c|}
\hline & $\operatorname{lnCO}_{2}$ & $\ln$ Agric & $\operatorname{lnInd}$ \\
\hline $\ln \mathrm{CO}_{2}$ & & -0.616283 & $1.765914^{*}$ \\
\hline $\ln$ Agric & $-1.783459^{*}$ & & 0.774347 \\
\hline $\ln$ Ind & -0.871681 & 0.124538 & \\
\hline
\end{tabular}

Short run causality tests were also conducted on the short run coefficients in the ARDL model environment using the Wald test. From Table 8, there is an indication that there is only unidirectional causality running from $\operatorname{lnCO}_{2}$ to $\ln$ Agric (at $10 \%$ significance) and lnInd to $\operatorname{lnCO}_{2}$ (also at $10 \%$ significance). This shows that agricultural output is affected by carbon emissions in the short run. The negative coefficient signifies that as carbon emissions increase, agricultural productivity falls. For $\ln I n d$ and $\ln \mathrm{CO}_{2}$, the coefficient is positive, meaning that industrial production increases carbon emissions. However, this is only in the short run and not in the long run. The observation is an indication that the industrialisation levels in South Africa are still low. Also, i t could be an indication that the mining sector is still relatively the largest sector than the manufacturing industry in South Africa. 


\section{Discussion}

From the results above, it is apparent that both industrial and agriculture production do not influence carbon emissions. This result suggests that the manufacturing sector has embarked on newer and efficient technologies, which lower the quantity of carbon emissions. In the same vein, the agricultural sector could be using less mechanized methods of production such that it does not produce much carbon emissions (Bennetzen et al., 2016). Of note is the strong relationship between agricultural production and both industrial output and carbon emissions. The indication is that a good manufacturing sector will cause more demand for agricultural products. With carbon emissions, it is a consequence of South Africa moving from high volume-low value agricultural output to low-volume-high value export-oriented production that is energy intensive. It is evident that in the long run, carbon emissions have an adverse effect on agricultural output, which further has implications on food security for the country.

In the short run, the expected relationship would be that increased production - both industrial and agricultural - would cause an increase in carbon emissions. However, this is only the case with carbon emissions and not agriculture production, albeit weak causality. It could be because this is a short run examination, or it could be that the economy might be growing and expanding in other sectors such as mining and construction. These other sectors may have an impact on carbon emissions that, in turn, affects the agricultural sectors. This is seen by the significant short run causality of carbon emissions on agricultural production. For the error correction models, there is evidence that carbon emissions affect agricultural production negatively and industrial production affects agriculture positively. As industrial production increases, usually due to economic growth, increased disposable incomes and demand, so too does agricultural production; this is because the industrial sector depends on the agricultural sector for raw materials. However, as carbon emissions increase, agricultural production falls due to the negative impact that carbon emissions have on plants and the environment.

\section{Conclusions}

This study sought to establish the link between carbon emissions, agricultural output and industrial output. The findings show that both agricultural and industrial output does not have a significant influence on carbon emissions in the long run. Instead, carbon emissions and industrial production influence agricultural output in the long run. This suggests that climate change resulting from carbon emissions has led to reduced agricultural output, adversely affecting food security. There is also a significant relationship between industrial and agricultural output, which suggests that there is a form of dependence running from the agriculture sector to the industrial sector. The possible link could be that the agricultural sector depends on the industrial sector for inputs and processing rather than vice versa. In addition, agricultural productivity is a source of autonomous demand for manufactured goods and income from agriculture leads to increased demand for mass-produced domestic goods. This induces increases in manufacturing output to meet demand. 
The study's findings have implications for climate change policies in South Africa as they show how each sector impacts on carbon emissions. For food security to improve, there is a need for strict control of carbon emissions as they affect agricultural production. Also, the link between agriculture and industry suggests that if the industrial sector is thriving, the agriculture sector can expand as well due to the positive interaction that exists between the two. The study has limitations in that only two aggregated sectors are used to ascertain the causal links between carbon emissions, agricultural output and industrial output. Further studies should consider breaking down the industrial and agricultural output to establish the sensitivity of each subsector. Finally, other estimation techniques like the vector error correction model should be considered in future research.

\section{References}

Agras, J., \& Chapman, D. (1999). A dynamic approach to the Environmental Kuznets Curve hypothesis. Ecological Economics, 28(2), 267-277. https://doi.org/10.1016/S0921-8009(98)00040-8

Alam, M. M., Murad, M. W., Noman, A. H. M., \& Ozturk, I. (2016). Relationships among carbon emissions, economic growth, energy consumption and population growth: Testing Environmental Kuznets Curve hypothesis for Brazil, China, India and Indonesia. Ecological Indicators, 70, 466-479. https://doi.org/10.1016/j.ecolind.2016.06.043

Altieri, M. A., \& Nicholls, C. I. (2017). The adaptation and mitigation potential of traditional agriculture in a changing climate. Climatic Change, 140(1), 33-45. https://doi.org/10.1007/s10584-013-0909-y

Apergis, N., \& Ozturk, I. (2015). Testing the Environmental Kuznets Curve hypothesis in Asian countries. Ecological Indicators, 52, 16-22. https://doi.org/10.1016/j.ecolind.2014.11.026

Arshed, N. (2014). A manual for ARDL approach to co-integration. Retrieved from https://nomanarshed. wordpress.com/2014/11/16/a-manual-for-ardl-approach-to-cointegration/

Asumadu-Sarkodie, S., \& Owusu, P. A. (2016). The relationship between carbon dioxide and agriculture in Ghana: A comparison of VECM and ARDL model. Environmental Science and Pollution Research, 23(11), 10968-10982. https://doi.org/10.1007/s11356-016-6252-x

Awokuse, T. O., \& Xie, R. (2015). Does agriculture really matter for economic growth in developing countries? Canadian Journal of Agricultural Economics/Revue Canadienne d'agroeconomie, 63(1), 77-99. https://doi.org/10.1111/cjag.12038

Bai, Y., Deng, X., Jiang, S., Zhao, Z., \& Miao, Y. (2018). Relationship between climate change and lowcarbon agricultural production: A case study in Hebei Province, China. Ecological Indicators, 15, 438-447. https://doi.org/10.1016/j.ecolind.2018.04.003

Begum, R. A., Sohag, K., Abdullah, S. M. S., \& Jaafar, M. (2015). $\mathrm{CO}_{2}$ emissions, energy consumption, economic and population growth in Malaysia. Renewable and Sustainable Energy Reviews, 41, 594601. https://doi.org/10.1016/j.rser.2014.07.205

Bennetzen, E. H., Smith, P., \& Porter, J. R. (2016). Agricultural production and greenhouse gas emissions from world regions - the major trends over 40 years. Global Environmental Change, 37, 43-55. https://doi.org/10.1016/j.gloenvcha.2015.12.004

Burke, P. J., Shahiduzzaman, M., \& Stern, D. I. (2015). Carbon dioxide emissions in the short run: The rate and sources of economic growth matter. Global Environmental Change, 33, 109-121. https://doi.org/10.1016/j.gloenvcha.2015.04.012

Chang, N. (2015). Changing industrial structure to reduce carbon dioxide emissions: a Chinese application. Journal of Cleaner Production, 103, 40-48. https://doi.org/10.1016/j.jclepro.2014.03.003 
Chen, W., Gao, P., \& He, J. (2004). Impacts of future carbon emission reductions on the Chinese GDP growth. Journal of Tsinghua University (Science and Technology), 44(6), 744-747.

Chen, Y. H. H., \& Timilsina, G. R. (2012). Economic implications of reducing carbon emissions from energy use and industrial processes in Brazil. The World Bank, Washington, DC. https://doi.org/10.1596/1813-9450-6135

Clark, M., \& Tilman, D. (2017). Comparative analysis of environmental impacts of agricultural production systems, agricultural input efficiency, and food choice. Environmental Research Letters, 12(6), 064016. https://doi.org/10.1088/1748-9326/aa6cd5

Cole, C. V., Duxbury, J., Freney, J., Heinemeyer, O., Minami, K., Mosier, A., Paustian, K., Rosenberg, N., Sampson, N., Sauerbeck, D., \& Zhao, Q. (1997). Global estimates of potential mitigation of greenhouse gas emissions by agriculture. Nutrient Cycling in Agroecosystems, 49(1-3), 221-228. https://doi.org/10.1023/A:1009731711346

Cole, V., Cerri, C., Minami, K., Mosier, A., Rosenberg, N., Sauerbeck, D., ... \& Heinemeyer, O. (1995). Agricultural options for mitigation of greenhouse gas emissions. In Climate Change (pp. 745-771). Cambridge University Press.

Davis, K. F., Gephart, J. A., Emery, K. A., Leach, A. M., Galloway, J. N., \& D’Odorico, P. (2016). Meeting future food demand with current agricultural resources. Global Environmental Change, 39, 125-132. https://doi.org/10.1016/j.gloenvcha.2016.05.004

de Souza, J. P. A. (2015). Evidence of growth complementarity between agriculture and industry in developing countries. Structural Change and Economic Dynamics, 34, 1-18. https://doi.org/10.1016/j.strueco.2015.05.001

Dinda, S. (2004). Environmental Kuznets Curve hypothesis: a survey. Ecological Economics, 49(4), 431455. https://doi.org/10.1016/j.ecolecon.2004.02.011

Du, Q., Zhou, J., Pan, T., Sun, Q., \& Wu, M. (2019). Relationship of carbon emissions and economic growth in China's construction industry. Journal of Cleaner Production, 220, 99-109. https://doi.org/10.1016/j.jclepro.2019.02.123

Fais, B., Sabio, N., \& Strachan, N. (2016). The critical role of the industrial sector in reaching long-term emission reduction, energy efficiency and renewable targets. Applied Energy, 162, 699-712. https://doi.org/10.1016/j.apenergy.2015.10.112

Feig, G. T., Joubert, W. R., Mudau, A. E., \& Monteiro, P. M. S. (2017). South African carbon observations: $\mathrm{CO}_{2}$ measurements for land, atmosphere and ocean. South African Journal of Science, 113 (11/12), 1-4. https://doi.org/10.17159/sajs.2017/a0237

Friel, S., Dangour, A. D., Garnett, T., Lock, K., Chalabi, Z., Roberts, I., ... \& Haines, A. (2009). Public health benefits of strategies to reduce greenhouse-gas emissions: food and agriculture. The Lancet, 374(9706), 2016-2025. https://doi.org/10.1016/S0140-6736(09)61753-0

Follett, R. F. (1993). Global climate change, US agriculture, and carbon dioxide. Journal of Production Agriculture, 6(2), 181-190. https://doi.org/10.2134/jpa1993.0181

Gold, M. V. (2016). Sustainable agriculture: the basics. CRC Press.

Goldbatt. (2018). Agriculture: facts and trends. South Africa. Retrieved from http: awsassets.wwf.org.za/ downloads/facts_brochure_mockup_04_b.pdf

Gollin, D., Jedwab, R., \& Vollrath, D. (2016). Urbanization with and without industrialization. Journal of Economic Growth, 21(1), 35-70. https://doi.org/10.1007/s10887-015-9121-4

Jebli, M. B., \& Youssef, S. B. (2017). The role of renewable energy and agriculture in reducing $\mathrm{CO}_{2}$ emissions: Evidence for North Africa countries. Ecological Indicators, 74, 295-301. https://doi.org/10.1016/j.ecolind.2016.11.032

Kanemoto, K., Moran, D., \& Hertwich, E. G. (2016). Mapping the carbon footprint of nations. Environmental Science \& Technology, 50(19), 10512-10517. https://doi.org/10.1021/acs.est.6b03227 
Keeling, C. D. (1973). Industrial production of carbon dioxide from fossil fuels and limestone. Tellus, 25(2), 174-198. https://doi.org/10.3402/tellusa.v25i2.9652

Kucukvar, M., Cansev, B., Egilmez, G., Onat, N. C., \& Samadi, H. (2016). Energy-climate-manufacturing nexus: New insights from the regional and global supply chains of manufacturing industries. Applied Energy, 184, 889-904. https://doi.org/10.1016/j.apenergy.2016.03.068

Kuznets, S. (1955). Economic growth and income inequality. American Economic Review, 45, 1-28.

$\mathrm{Li}, \mathrm{K}$., \& Lin, B. (2015). Impacts of urbanization and industrialization on energy consumption/ $\mathrm{CO}_{2}$ emissions: does the level of development matter? Renewable and Sustainable Energy Reviews, 52, 1107-1122. https://doi.org/10.1016/j.rser.2015.07.185

Li, T., Baležentis, T., Makutenienė, D., Streimikiene, D., \& Kriščiukaitienė, I. (2016). Energy-related $\mathrm{CO}_{2}$ emission in European Union agriculture: Driving forces and possibilities for reduction. Applied Energy, 180, 682-694. https://doi.org/10.1016/j.apenergy.2016.08.031

Liaskas, K., Mavrotas, G., Mandaraka, M., \& Diakoulaki, D. (2000). Decomposition of industrial $\mathrm{CO}_{2}$ emissions:: The case of the European Union. Energy Economics, 22(4), 383-394. https://doi.org/10.1016/S0140-9883(99)00035-3

Lin, B., \& Lei, X. (2015). Carbon emissions reduction in China’s food industry. Energy Policy, 86, 483492. https://doi.org/10.1016/j.enpol.2015.07.030

Lin, B., \& Xie, X. (2016). $\mathrm{CO}_{2}$ emissions of China’s food industry: an input-output approach. Journal of Cleaner Production, 112, 1410-1421. https://doi.org/10.1016/j.jclepro.2015.06.119

Liu, L. C., Fan, Y., Wu, G., \& Wei, Y. M. (2007). Using the LMDI method to analyze the change of China's industrial $\mathrm{CO}_{2}$ emissions from final fuel use: An empirical analysis. Energy Policy, 35(11), 5892-5900. https://doi.org/10.1016/j.enpol.2007.07.010

Liu, L. C., Wang, J. N., Wu, G., \& Wei, Y. M. (2010). China’s regional carbon emissions change over 1997-2007. International Journal of Energy and Environment, 1(1), 161-176.

Long, X., Luo, Y., Wu, C., \& Zhang, J. (2018). The influencing factors of $\mathrm{CO}_{2}$ emission intensity of Chinese agriculture from 1997 to 2014. Environmental Science and Pollution Research, 25(13), 1309313101. https://doi.org/10.1007/s11356-018-1549-6

Ma, X., Wang, C., Dong, B., Gu, G., Chen, R., Li, Y., Zou, H., Zhang, W., \& Li, Q. (2019). Carbon emissions from energy consumption in China: Its measurement and driving factors. Science of the Total Environment, 648, 1411-1420. https://doi.org/10.1016/j.scitotenv.2018.08.183

Mi, Z. F., Pan, S. Y., Yu, H., \& Wei, Y. M. (2015). Potential impacts of industrial structure on energy consumption and $\mathrm{CO}_{2}$ emission: a case study of Beijing. Journal of Cleaner Production, 103, 455462. https://doi.org/10.1016/j.jclepro.2014.06.011

Moore, F. C., \& Diaz, D. B. (2015). Temperature impacts on economic growth warrant stringent mitigation policy. Nature Climate Change, 5(2), 127-131. https://doi.org/10.1038/nclimate2481

Pant, K. P. (2009). Effects of agriculture on climate change: a cross-country study of factors affecting carbon emissions. Journal of Agriculture and Environment, 10, 84-102. https://doi.org/10.3126/aej.v10i0.2134

Pesaran, H. H., \& Shin, Y. (1998). Generalized impulse response analysis in linear multivariate models. Economics Letters, 58(1), 17-29. https://doi.org/10.1016/S0165-1765(97)00214-0

Pesaran, M. H., \& Pesaran, B. (1997). Working with Microfit 4.0: interactive econometric analysis [Windows version]. Oxford University Press.

Pesaran, M. H., Shin, Y., \& Smith, R. J. (2001). Bounds testing approaches to the analysis of level relationships. Journal of Applied Econometrics, 16(3), 289-326. https://doi.org/10.1002/jae.616

Sarkodie, S. A., \& Strezov, V. (2018). An empirical study of the Environmental Kuznets curve and Environmental Sustainability curve hypothesis for Australia, China, Ghana and the USA. Journal of Cleaner Production, 201, 98-110. https://doi.org/10.1016/j.jclepro.2018.08.039 
Sauerbeck, D. R. (2001). $\mathrm{CO}_{2}$ emissions and $\mathrm{C}$ sequestration by agriculture-perspectives and limitations. Nutrient Cycling in Agroecosystems, 60(1-3), 253-266. https://doi.org/10.1023/A:1012617516477

Smith, P., Martino, D., Cai, Z., Gwary, D., Janzen, H., Kumar, P., McCarl, B., Ogle, S., O’Mara, F., Rice, C., Scholes, B., Sirotenko, O., Howden, M., McAllister, T., Pan, G., Romanenkov, V., Schneider, U., Towprayoon, S., Wattenbach, M., \& Smith, J. (2007). Greenhouse gas mitigation in agriculture. Philosophical Transactions of the Royal Society B: Biological Sciences, 363(1492), 789-813. https://doi.org/10.1098/rstb.2007.2184

Statistics South Africa. (2019). Retrieved from http://www.statssa.gov.za/

Uddin, M. M. M. (2015). Causal relationship between agriculture, industry and services sector for GDP growth in Bangladesh: An Econometric Investigation. Journal of Poverty, Investment and Development, 8, 124-129.

Van Vuuren, D. P., Stehfest, E., Gernaat, D. E., Doelman, J. C., Van den Berg, M., Harmsen, M., ... \& Girod, B. (2017). Energy, land-use and greenhouse gas emissions trajectories under a green growth paradigm. Global Environmental Change, 42, 237-250.

https://doi.org/10.1016/j.gloenvcha.2016.05.008

Victor, P. A. (2017). Pollution: Economy and environment. London: Routledge. https://doi.org/10.4324/9781315108483

Wang, H., Zhang, R., Liu, M., \& Bi, J. (2012). The carbon emissions of Chinese cities. Atmospheric Chemistry and Physics, 12(14), 6197-6206. https://doi.org/10.5194/acp-12-6197-2012

Wang, Z., \& Yang, L. (2015). Delinking indicators on regional industry development and carbon emissions: Beijing-Tianjin-Hebei economic band case. Ecological Indicators, 48, 41-48. https://doi.org/10.1016/j.ecolind.2014.07.035

$\mathrm{Xu}, \mathrm{B} .$, \& Lin, B. (2015). How industrialization and urbanization process impacts on $\mathrm{CO}_{2}$ emissions in China: evidence from nonparametric additive regression models. Energy Economics, 48, 188-202. https://doi.org/10.1016/j.eneco.2015.01.005

Xu, S. C., He, Z. X., \& Long, R. Y. (2014). Factors that influence carbon emissions due to energy consumption in China: Decomposition analysis using LMDI. Applied Energy, 127, 182-193. https://doi.org/10.1016/j.apenergy.2014.03.093

Xu, S. C., He, Z. X., Long, R. Y., \& Chen, H. (2016). Factors that influence carbon emissions due to energy consumption based on different stages and sectors in China. Journal of Cleaner Production, 115, 139-148. https://doi.org/10.1016/j.jclepro.2015.11.050

Zhang, L., Pang, J., Chen, X., \& Lu, Z. (2019). Carbon emissions, energy consumption and economic growth: Evidence from the agricultural sector of China's main grain-producing areas. Science of the Total Environment, 665, 1017-1025. https://doi.org/10.1016/j.scitotenv.2019.02.162 